\title{
THE INTERFACE BETWEEN FEDERAL AND PROVINCIAL JURISDICTION OVER PIPELINES: RECENT DEVELOPMENTS, CURRENT ISSUES AND A SUGGESTED MECHANISM FOR REDUCING TURBULENCE IN THE BUFFER ZONE
}

\section{ROWLAND J. HARRISON ${ }^{*}$}

\begin{abstract}
In two recent decisions of the Federal Court of Appeal, the Court overruled the National Energy Board's determination of the extent of the Board's constitutional jurisdiction with respect to interprovincial pipelines and cerlain associated facilities. A necessary conclusion to be drawn from these, and earlier, cases is that, in the absence of a final judicial ruling on specific facilities, the jurisdictional status of many facilities will always be in some doubt. This article examines the possibility of employing mechanisms that are wellestablished within the framework of the Constitution Act, 1867 to mitigate the consequences of this uncertainty. This is the first time that the viability of using such mechanisms in this context has been analyzed in detail.
\end{abstract}

\section{TABLE OF CONTENTS}

I. INTRODUCTION ..................... 389

II. APPLICABLE PRINCIPLES $\ldots \ldots \ldots \ldots \ldots \ldots \ldots \ldots \ldots . \ldots \ldots 2$

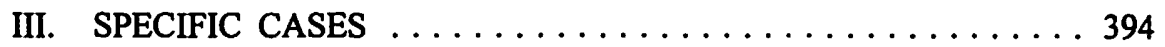

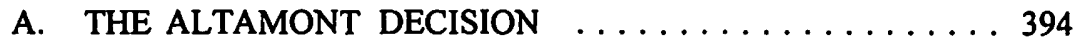

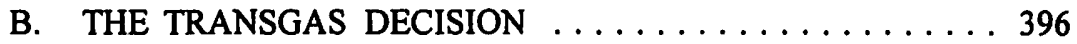

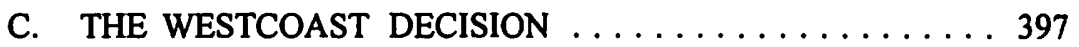

D. THE CONSUMERS' DECISION $\ldots \ldots \ldots \ldots \ldots \ldots \ldots 400$

E. THE PESH CREEK PIPELINE $\ldots \ldots \ldots \ldots \ldots \ldots \ldots 400$

F. EMERGING ISSUES $\ldots \ldots \ldots \ldots \ldots \ldots \ldots \ldots \ldots$

IV. SOURCE OF THE PROBLEM $\ldots \ldots \ldots \ldots \ldots \ldots \ldots \ldots 402$

V. A SUGGESTED SOLUTION $\ldots \ldots \ldots \ldots \ldots \ldots \ldots \ldots 404$

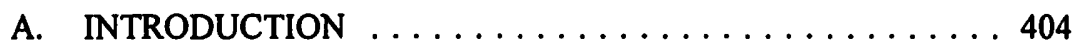

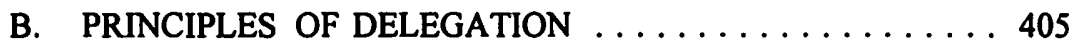

C. APPLICATION TO FEDERAL PIPELINES $\ldots \ldots \ldots \ldots 407$

VI. CONCLUSION $\ldots \ldots \ldots \ldots \ldots \ldots \ldots \ldots \ldots \ldots \ldots \ldots$

\section{INTRODUCTION}

Recent developments before the National Energy Board ("NEB" or "Board") and judicial decisions reviewing two specific Board proceedings have cast a pall of uncertainty over the dividing line between federal and provincial jurisdiction in relation to interprovincial pipelines and their associated facilities. While there now seems to be a consensus that the relevant legal principles are both settled and clear, these developments suggest that the application of such principles is as problematic as ever. Therefore, in the absence of a final judicial ruling specific to each particular facility, the jurisdictional status of many facilities will continue to be uncertain. 
The difficulties inherent in the application of these principles are emphasized by the fact that, in two recent decisions, the Federal Court of Appeal set aside the NEB's rulings on the extent of the Board's constitutional jurisdiction in relation to specific pipeline facilities. In the first of these' the NEB had ruled, in a majority decision of two to one, that the Board did not have jurisdiction over certain new and expansion facilities for which Westcoast Energy Inc. ("Westcoast") had sought various approvals. The Federal Court of Appeal, in a unanimous decision in Westcoast Energy Inc. v. Canada (National Energy Board), ${ }^{2}$ ruled that the relevant facilities were indeed within the jurisdiction of the Board and that Westcoast was "a single undertaking engaged in the interprovincial and international transportation of natural gas." ${ }^{3}$ In the second decision, ${ }^{4}$ the Board had originally ruled, again in a majority decision, this time four to two, that its jurisdiction extended to certain existing facilities forming part of The Consumers' Gas Company Ltd. ("Consumers') system. In another unanimous decision in Consumers' Gas Company v. Canada (National Energy Board), ${ }^{5}$ the Federal Court of Appeal concluded that elements of the Board's finding were "fundamentally flawed"6 and that the Board's jurisdiction did not extend to Consumers' Ottawa East Line as the Board had ruled.

For the purpose of this article, the principal question is not so much how it was that the NEB had erred in arriving at its decisions on jurisdiction. These decisions are reviewed here, but only to explore whether there are mechanisms within the framework of the Constitution Act, $1867^{7}$ that could be employed to mitigate the consequences for industry arising from jurisdictional uncertainty. Recent developments, both before the Board and in the Federal Court of Appeal, indicate the need to pursue this inquiry.

It is worth emphasizing that these recent developments have not come about as a result of any uncertainty with respect to the legal principles to be applied. As noted by the Federal Court of Appeal in the Westcoast Case and the Consumers' Case, and indeed by the Board itself, ${ }^{8}$ these principles have been stated authoritatively by the Supreme Court of Canada. ${ }^{9}$ Furthermore, this clarity with respect to applicable principles pre-dates these recent developments, thereby emphasizing that the difficulty arises from the application of the principles to each specific set of facts. Jurisdictional uncertainty will, therefore, persist.

In the Matter of Westcoast Energy Inc. Application dated 6 October 1994, as amended, for the Fort St. John Expansion Project (May 1995), No. GH-5-94 (NEB) [hereinafter Westcoast Jurisdiction Decision].

(1996), 134 D.L.R. (4th) 114 (Fed. C.A.) [hereinafter Westcoast Case].

Ibid. at 137.

In the Matter of Niagara Gas Transmission Ltd. Letter dated 2I July 1995 from Consumers' Gas requesting a decision on the jurisdictional question raised by the National Energy Board in its letter of 19 May 1994 (September 1995), (NEB) [hereinafter Niagara Decision]. NEB Vice Chairman K.W. Vollman and Member A. Cotte-Verhaaf were in the majority in both this and the Westcoast Jurisdiction Decision and Member R. Illing dissented in both cases.

(1996), 195 N.R. 150 (Fed. C.A.) [hereinafter Consumers' Case].

Ibid. at 153.

(U.K.), 30 \& 31 Vict., c. 3.

See e.g. supra note 1 at 8.

See also discussion infra note 20 and accompanying text. 
In a 1991 article, John B. Ballem concluded that, "[w]ith the emergence of the 'essential' test as the governing principle, one should be able to examine certain aspects of pipeline operations in Canada and predict their jurisdictional fate with some level of confidence."10 In retrospect, this conclusion appears to have been unduly optimistic.

Always lurking in the background in any discussion of this topic are the implications for the jurisdictional status of the NOVA Gas Transmission Ltd. ("NGTL") system. Provincial authority over NGTL has been sacrosanct since the establishment of NGTL's predecessor, The Alberta Gas Trunk Line Company Ltd. ("AGTL") by special Act of the Alberta legislature effective April 8, 1954." Indeed, AGTL was created for the very purpose of preventing the encroachment of federal jurisdiction into the management of the province's oil and gas resources and to "strengthen the control of gas within the province by provincial authorities."12

On the other hand, the Westcoast system in British Columbia was originally built as an export project and, as such, came under exclusive federal jurisdiction from its inception. ${ }^{13}$ The Federal Court of Appeal has confirmed in the recent Westcoast Case that Westcoast operates a single undertaking that includes gathering, processing and transporting natural gas and that exclusive federal jurisdiction extends to all such components of its business. ${ }^{14}$

Whatever the legal explanation for the difference in treatment between the Westcoast and the NGTL systems, the result must appear to an outside observer to be somewhat anomalous - there is exclusive federal jurisdiction with respect to the whole of the Westcoast system in British Columbia; while at the same time, there is no federal jurisdiction with respect to any part of the NGTL system in the neighbouring province, or so it is widely believed (or, perhaps, hoped).

Of course, arguments can be made that the undertakings of the two systems are not the same and that there is therefore no anomaly, but to the non-lawyer such arguments must often seem to depend on the drawing of distinctions without a difference.

In any event, it is legitimate to ask whether, from a regulatory perspective, the two systems should be treated so differently and, if not, whether there are mechanisms available that could be engaged to produce a different result. Accepting, as we must, the assignment of jurisdiction as the courts tell us, is it nevertheless legally possible to

"Pipelines and the Federal Transportation Power" (1991) 29 Alta. L. Rev. 617 at 627.

Alberta Gas Trunk Line Company Act, S.A. 1954, c. 37.

D.M. Breen, Alberta's Petroleum Industry and the Conservation Board (Edmonton: University of Alberta Press, 1993) at 399, citing Petroleum and Natural Gas Conservation Board, Report to the Lieutenant Governor in Council With Respect to the Application under the Gas Resources Preservation Act of: Canadian-Montana Pipeline Co.; TransCanada PipeLines Lid.. Trans-Canada Grid of Alberta Lid., and Canadian Delhi Oil Lid.; and Western Pipe Lines (24 November 1953) at 11 and 99-106.

See generally Breen, ibid, c. 6, especially at $370 \mathrm{ff}$.

See also supra note 1 at 22 . 
bring about a different result (at least for all practical purposes) if it is determined that this would be desirable?

The position taken by the government of British Columbia before the NEB in the Westcoast Jurisdiction Decision is noteworthy in this context. The Board summarized it as follows:

\begin{abstract}
The British Columbia Ministry of Energy, Mines and Petroleum Resources submitted that the Province of British Columbia should regulate gathering and processing because of the significant influence these activities have on the development of the natural gas resources in the province. Beyond this, however, the Ministry made no submissions on the jurisdictional issue, stating that it was the view of the government of British Columbia that this was a policy matter which should be addressed by the federal and provincial govemments. ${ }^{\text {is }}$
\end{abstract}

\title{
II. APPLICABLE PRINCIPLES
}

Federal jurisdiction in relation to pipelines and their associated facilities arises under the Constitution Act, 1867 by way of exception from the assignment to the provincial legislatures of legislative authority in relation to local works and undertakings. The relevant provision is paragraph $92(10)(a)$, which assigns to the legislatures exclusive authority to make laws in relation to matters coming within the following class of subject:

10. Local Works and Undertakings other than such as are of the following Classes:-

(a) Lines of Steam or other Ships, Railways, Canals, Telegraphs, and other Works and Undertakings connecting the Province with any other or others of the Provinces, or extending beyond the Limits of the Province. [emphasis added]

Subsection 91(29) of the Constitution Act, 1867 expressly provides that the classes of subjects assigned to the federal legislative power include such as are expressly excepted in the enumeration of classes of subjects assigned exclusively to the legislatures of the provinces. The result is that exclusive legislative authority in relation to the items enumerated in paragraph $92(10)(a)$ is assigned to the federal Parliament as if paragraph (a) had been included among the classes of subjects specifically enumerated in $\mathbf{5} .91$.

The interpretation of this provision has a long history, ${ }^{16}$ and includes a number of judicial decisions that form part of the lore of Canadian constitutional jurisprudence, such as those of the Privy Council in (A.G.) Ontario v. Winner ${ }^{17}$ and C.P.R. v. British Columbia (A.G.). ${ }^{18}$

\footnotetext{
Supra note 1 at 6.

See generally P.W. Hogg, Constitutional Law of Canada, 3d ed. (Toronto: Carswell, 1992), c. 22. [1954] A.C. 541 (P.C.).

[1950] A.C. 122 (P.C.).
} 
Now, however, the relevant principles appear to be settled and accepted. In the Consumers' Case the Federal Court of Appeal referred to "the now classic two part test"19 articulated by Dickson C.J. in 1990, in United Transportation Union v. Central Western Railway Corp., as follows:

There are two ways in which Central Western may be found to fall within federal jurisdiction ... First, it may be seen as an interprovincial railway and therefore come under s. 92(10)(a) of the Constitution $A c t, 1867$ as a federal work or undertaking. Second, if the appellant can be properly viewed as integral to an existing federal work or undertaking it would be subject to federal jurisdiction under s. 92(10)(a). For clarity, I should point out that these two approaches, though not unrelated, are distinct from one another. For the former, the emphasis must be on determining whether the railway is itself an interprovincial work or undertaking. Under the latter, however, jurisdiction is dependent upon a finding that regulation of the subject matter in question is integral to a core federal work or undertaking. ${ }^{20}$

A specific work or undertaking may, in other words, come within federal jurisdiction because it is itself an interprovincial work or undertaking. A pipeline crossing a provincial boundary is an obvious example. Even if a specific work or undertaking is not itself an interprovincial work or undertaking, it will nevertheless be characterized as such for jurisdictional purposes if it is integral to an interprovincial work or undertaking.

It will be immediately apparent that each branch of this seemingly simple two-part test for determining jurisdiction under paragraph 92(10)(a) begs a number of questions. The characterization of a physical work as interprovincial may be relatively simple, but how does one determine whether an undertaking is interprovincial? Under the second branch of the test, what are the ingredients that will make a work or undertaking integral to a core federal work or undertaking? The Board has stated that the answer to this latter question requires "a consideration of the particular constitutional facts concerning the line as related to physical connection, effective ownership, control, and general operational and functional integration." ${ }^{21}$

As the Westcoast Case and Consumers' Case graphically illustrate, a clear statement of principle is merely a point of departure and is not itself sufficient to avoid jurisdictional uncertainty - the application of such principle to specific cases can still be fraught with difficulty. It was apparent from the Supreme Court's analysis in the Central Western decision that the outcome in every case will be determined on its own facts. ${ }^{22}$ 


\section{SPECIFIC CASES}

\section{A. THE ALTAMONT DECISION}

A convenient point of departure for present purposes is the February 1993 decision of the NEB on an application by Altamont Gas Transmission Canada Ltd. ("Altamont Canada"). ${ }^{23}$ In this decision, the Board, on its own initiative, posed a preliminary question of jurisdiction as to whether Altamont Canada's application for a "sausage link" connection, or "bridge" pipeline, to proposed facilities of NOVA Corporation of Alberta ("NOVA" as NGTL was known then), was properly before the Board. ${ }^{24}$

Figure 1 at p. 409 of this article illustrates the issue. ${ }^{25}$

As appears from this figure, Altamont Canada's application to the NEB was confined to a $\mathbf{3 0 0}$ metre section of pipe that would connect the U.S. portion of the Altamont project from the Canada-U.S. border to a proposed new line, identified as the Wild Horse Mainline, to be constructed by NOVA from Princess, Alberta.

The Board directed that the following preliminary question of jurisdiction be considered:

Is the proposed pipeline of the applicant part of a larger extraprovincial work to be constructed from a point near Princess, Alberta to a point of connection in the United States, the entire Canadian portion of which is subject to the jurisdiction of Parliament pursuant to s. 92(10)(a) of the Constitution Act 1867, having regard to the following factors:

(a) the physical connections between the pipelines of NOVA Corporation of Alberta, Altamont Gas Transmission Canada Limited, and Altamont Gas Transmission Company;

(b) the operation of the NOVA Corporation of Alberta and Altamont Gas Transmission Canada Limited pipelines as a line wholly or substantially dedicated to the export of a commodity from Canada; and

(c) the purposes to be served by the construction of the pipelines of NOVA Corporation of Alberta and Altamont Gas Transmission Canada Limited. ${ }^{25}$

In a majority decision of seven to two, the Board answered this question in the affirmative.

In the Matter of Altamont Gas Transmission Canada Limited Application dated 26 July 1991 for Gas Transmission Pipeline Facilities Preliminary Question of Jurisdiction (February 1993), No. GHW-1-92 (NEB) [hereinafter Altamont Decision]. referred to a list of seventeen bridge gas pipelines which the Board had approved and continued to regulate, ibid at 28. 
The Board applied the Central Western decision and concluded:

The constitutional classification of a pipeline will, therefore, be determined on the basis of a consideration of the particular constitutional facts concerning that pipeline as related to physical connection, effect of ownership, control, and general operational and functional integration. ${ }^{27}$

Applying these tests to the Altamont Canada Line/NOVA Wild Horse Mainline, the majority of the Board found that the line came within both limbs of the Central Western test. First, it concluded that

the work to be constructed between Princess, Alberta, and the United States, as presently contemplated, would be subject to federal jurisdiction because it would constitute one work connecting the province of Alberta and the United States of America. ${ }^{28}$

\section{Secondly,}

[e]ven if the Board is incorrect in its view that the entire line from Princess to the international border is itself one work connecting the province of Alberta with the United States of America, an analysis of the facts before the Board shows that the Wild Horse Mainline is so closely connected with, or so essential to, the Altamont Canada line as to cause the proposed NOVA Wild Horse Mainline to lose its characteristics as a provincial work and become, together with the Altamont Canada line, one pipeline subject to federal jurisdiction. ${ }^{29}$

In a strong dissenting opinion, the then - Vice Chairman of the Board, J.-G. Fredette, disagreed with his colleagues, not only with respect to their conclusions on the merits, but also with respect to the Board's decision to ask the preliminary question of jurisdiction in the first instance. ${ }^{30}$

Altamont Canada applied to the Federal Court of Appeal for leave to appeal the Board's decision. Subsequently, however, a fresh application to construct the Wild Horse Line was filed with the Board by Foothills Pipe Lines (Alta.) Ltd. ("Foothills") in substitution for the Altamont Canada application, thereby rendering Altamont Canada's appeal academic. ${ }^{31}$ The appeal was formally withdrawn. ${ }^{32}$

Ibid. at 19.

Ibid. at 20.

Ibid. at 21 .

Ibid., c. 6. Board Member C. Bélanger also dissented both with respect to the majority's decision to raise the preliminary question of jurisdiction and with respect to its conclusion on the substantive issue, ibid. at $\mathbf{4 6 - 4 7}$.

An application by Foothills to the NEB did not pose a threat to the intrusion of NEB jurisdiction into any part of the NOVA system. The Foothills application was approved by the Board in a decision released on January 26, 1995: In the Matter of Foothills Pipe Lines (Alta.) Lid. Application dated 30 June 1994 for the Wild Horse Pipeline Project, (January 26, 1995), No. GH4-94 (NEB) [hereinafter Wild Horse Decision].

On April 26, 1993. 
We are, therefore, left to speculate as to the view that the Federal Court of Appeal would have taken and whether the Board came close to having its jurisdiction over part of the NOVA system confirmed. It cannot escape notice that the only significant difference between the overall projects as originally proposed by Altamont Canada, and as subsequently proposed by Foothills, was the applicant. The Board's jurisdiction over the whole of the Wild Horse Line was not questioned when approval for that line was requested by Foothills, yet the Board's suggestion that virtually the same line (upstream from the border crossing itself) would be under its jurisdiction was vigorously challenged when it was proposed that the line be constructed and operated by NOVA. There was really no difference between the two applications with respect to the purpose or intended operation of the line from Princess to the international border. It is at least doubtful, particularly having regard to the analysis in the Federal Court of Appeal's recent decisions in the Westcoast Case and the Consumers' Case, that this difference alone would have been sufficient to produce a different conclusion with respect to jurisdiction.

\section{B. THE TRANSGAS DECISION}

For the sake of completeness, brief reference should also be made to the Board's decision dated February 25, 1993, to deny an application by WBI Canadian Pipeline, Ltd. ("WBI Canadian") to construct a 1.15-kilometre pipeline crossing the international border in the vicinity of North Portal, Saskatchewan. The application was denied on the ground that the pipeline was part of a larger extraprovincial work connecting the province of Saskatchewan to the U.S. The Board found that a proposed new pipeline to be constructed by TransGas Limited ("TransGas") extending from Steelman to North Portal, and to which the proposed WBI Canadian line would connect, was integral and essential to the WBI Canadian line and that the two lines, when joined and operations commenced, would constitute a federal work and undertaking within the jurisdiction of the Board ${ }^{33}$ TransGas applied to the Federal Court of Appeal for leave to appeal the Board's decision and also applied for a review of the decision by the Board itself. ${ }^{34}$

The Board subsequently granted the application for review of its earlier decision and approved the WBI Canadian application, while maintaining its position that the approved line would, when connected to the proposed TransGas line, constitute together with that line a single work under federal jurisdiction. ${ }^{35}$

The implications of the Board's initial decisions with respect to both the Altamont Canada and the WBI Canadian applications were captured in the following comment:

These decisions raise serious questions about the remainder of the NOVA system which continues to be subject to regulation by Alberta authorities. The NEB majority in Altamont was careful to point out

3s TransGas' application for leave to appeal to the Federal Court of Appeal was withdrawn on January 5, 1994. 
that its review and decision are restricted to the particular NOVA facility, and that it is unnecessary to examine the balance of the NOVA system. However, the Altamont majority members did note that failure by one level of government to exercise constitutional jurisdiction confers no jurisdiction on the other level. The fact-sensitive nature of the constitutional tests produces uncertainty about the constitutional status of the remainder of the NOVA system, particularly since respected commentators have concluded that it is likely that NOVA's system is an essential component of the federally regulated extraprovincial pipelines that it supplies. (See J.B. Ballem, "Pipelines and the Federal Transportation Power" (1991) 29 Alta L. Rev. 617.) A conclusion that the NOVA system is subject to federal jurisdiction would produce new strains on relations between the federal and Alberta governments. ${ }^{36}$

\section{THE WESTCOAST DECISION}

The recent Westcoast Case decided by the Federal Court of Appeal arose from two applications by Westcoast for the approval of proposed new and expansion facilities. ${ }^{37}$

The first such application related to the proposed Fort St. John Expansion Project and became the subject of the Board's May 1995 Westcoast Jurisdiction Decision. ${ }^{38}$ Westcoast had applied to the Board for a certificate of public convenience and necessity authorizing the installation of two pipeline loops; an order authorizing the construction of a new Aitken Creek plant, three compressor unit additions, and expansion of the Fort St. John Raw Gas Transmission ("RGT") system; and an order requesting a rolled-in toll for services provided by the applied-for facilities. ${ }^{39}$

The specific facilities comprising the Fort St. John Expansion Project are illustrated in Figure 2 at p. 410 of this article, taken from the Board's Reasons for Decision. ${ }^{40}$

The Board acknowledged that it had historically exercised jurisdiction over all of Westcoast's operations, ${ }^{41}$ but also noted that its jurisdiction over Westcoast's gathering and processing facilities had never before been formally challenged. ${ }^{42}$

The Board concluded that the proposed facilities would not be part of Westcoast's mainline transmission undertaking, with the exception of the proposed loop of the Aitken Creek pipeline that would connect the new Aitken Creek plant with Westcoast's new transmission line. It therefore dismissed Westcoast's application with respect to all

41

42

A.R. Lucas, "Recent Developments - National Energy Board — Constitutional Jurisdiction over Pipelines" (1993) 11 J.E.R.L. 295 at 296.

Supra note 2.

Supra note 1.

The description of Westcoast's application is taken from the Board's February 1996 decision approving the applied-for facilities. See In the Matter of Westcoast Energy Inc. Application dated 6 October 1994, as amended, for Fort St. John Expansion Project (February 1996), No. GH-5-94 (NEB) at 1.

Figure 2 is reproduced with the permission of the National Energy Board, ibid.

Supra note 1 at 7.

Except with respect to two specific components of the system: the Sukunka fuel gas line and the liquid products stabilization and fractionation facilities at Westcoast's McMahon plant in both of which cases the Board had found that it had jurisdiction over the facilities in question. See ibid. 
facilities except for the proposed Aitken Creek pipeline loop. As that loop would not be needed until the new Aitken Creek plant was built, however, the Board also declined to approve the loop at that time. ${ }^{43}$

Westcoast applied for and was granted leave to appeal the decision to the Federal Court of Appeal.

Westcoast had earlier applied for a further facilities approval for the Grizzly Valley Expansion Project, to include the Tumbler Ridge Gas Plant, two compressor units, an expansion of the Grizzly Valley RGT system, and a residue gas pipeline. ${ }^{44}$ As the application raised jurisdictional issues similar to those in the Fort St. John matter, the Board referred the question to the Federal Court of Appeal where the reference was combined with the appeal from the Westcoast Jurisdiction Decision, leading to the Court's combined Westcoast Case decision. ${ }^{45}$

In overruling the Board, the Court relied heavily on the statement of facts forming part of the order of reference and concluded that "it [is] impossible to read this description without concluding that Westcoast is engaged in a single undertaking comprised of the business of gathering, processing and transporting natural gas." ${ }^{.46}$ The Court found that it was unnecessary to deal with the essential and integral test under the second branch of the Central Western test. ${ }^{47}$

As already noted, it is not the primary purpose of this article to dissect the reasons for the conclusions of either the Board or the Federal Court of Appeal. Nevertheless, there are some points of particular note in the Court's reasons for judgment in the Westcoast Case.

First, the Court stated that the primary determination, based on the principles articulated in the Central Western decision, ${ }^{48}$ is whether the relevant facilities constitute one undertaking or more than one. The Court emphasized that "[t]his involves an inquiry into the actual operation of the Westcoast System as it presently exists and functions. ${ }^{149}$ The question was not "how the enterprise might have been structured or how other people in fact operate and structure different enterprises." ${ }^{50}$ This emphasizes even further the fact-dependent nature of the problem and, in turn, the need for judicial rulings specific to individual facilities.

Ibid. at 9-10, 12. The Board's decision was described at the time as a "stunning setback." See J. Schreiner, "Westcoast Stunned by Surprise NEB Ruling" The Financial Post (27 May 1995) 5. Supra note 39 at 4. Westcoast's Grizzly Valley Expansion application became the subject of Board Hearing Order GH-6-94.

Supra note 2.

Ibid. at 132.

Ibid. at 141.

Supra note 20.

Supra note 2 at 126 [emphasis added].

Ibid. 
Secondly, the Court emphasized a significant distinction between, on the one hand, the fact of ownership simpliciter and, on the other hand, ownership combined with control:

[M]uch is made of the undoubted fact that ownership is not, by itself, determinative of constitutional jurisdiction. That, however, is a very different thing from saying that ownership, together with its attendant control and direction, is irrelevant to the question of jurisdiction. ${ }^{31}$

Thirdly, the Court rejected an argument that s. 92A of the Constitution Act, 1867, and in particular paragraph (1)(b) thereof relating to the "development, conservation and management of non-renewable natural resources and forestry resources in the province," could be read as "preventing the exercise of federal jurisdiction over a transportation undertaking which receives raw gas from the producers thereof after it has been extracted from the ground, dehydrated, and transported to delivery points." In the Court's view, "[s]uch federal jurisdiction is entirely compatible with the exercise of the provincial powers mentioned in s. 92A." 52

Fourthly, the Court was careful to confine its conclusions to the gathering and processing facilities owned and operated by Westcoast and emphasized that its finding with respect to those facilities "does not necessarily establish that the gathering and processing operations carried on by others are vital or essential to the Westcoast undertaking so as to become themselves subject to federal jurisdiction." As the Court noted, "[t]hat is a question for another day...." 53

Finally, it is worth noting that the Westcoast Case was also concerned with a question of statutory interpretation: specifically, the definition of "pipeline" under s. 2 of the National Energy Board Act. ${ }^{54}$ It was argued that the definition was not sufficiently broad to include the Westcoast processing plants. The Federal Court of Appeal had little difficulty in concluding that the definition was sufficiently broad. ${ }^{55}$

For present purposes, however, the most significant point arising from the Westcoast decision is that the delay caused by jurisdictional uncertainty, and the need to resort to the courts to resolve that uncertainty, resulted in both the Fort St. John Expansion Project and the Grizzly Valley Expansion Project being shelved. ${ }^{56}$ This was notwithstanding the fact that, following the Federal Court of Appeal decision, the NEB moved promptly to consider Westcoast's Fort St. John application on its merits and grant the approvals requested. ${ }^{57}$

Ibid. at 134.

Ibid. at 139.

lbid. at 141-42.

R.S.C. 1985 , c. N-7 [hereinafter NEB Act].

Supra note 2 at 142.

See "Westcoast Energy Inc. Allowed to Proceed with Plant Project" The Financial Post (14 February 1996).

Supra note 39. 


\section{THE CONSUMERS' DECISION}

The decision of the Federal Court of Appeal in the Consumers' Case arose from the NEB's decision in September 1995, on an application by Niagara Gas Transmission Ltd. for approval of facilities to cross the Ottawa River and link the Consumers' system on the Ontario side with the Hull local distribution company, Gazifère Inc. ${ }^{58}$ The specific facilities and the configuration of the Consumers' system in the region are illustrated in Figure 3 at p. 411 of this article, taken from the Board's Reasons for Decision. ${ }^{59}$

A majority of the Board concluded that Consumers' Ottawa East line, once connected to the Niagara line, would be subject to federal jurisdiction as being vital, integral and essential to Niagara's admittedly interprovincial line. The Board found that federal jurisdiction would commence "where the TransCanada line connects with the Consumers' Gas line at the property line of the Ottawa Gate Station and includes the Ottawa Gate Station which encompasses all pipelines, facilities and installations within the station's property lines. ${ }^{160}$ The Board thereby purported to assume jurisdiction over existing Consumers' facilities that had clearly been constructed and were operated as a local work under provincial authority, quite independently of the Niagara line, and, indeed, before the line had even been proposed. Furthermore, as the Board was aware, no party to the proceeding had submitted that the Ottawa East line was subject to federal jurisdiction. ${ }^{61}$

The Federal Court of Appeal granted the appeal in terms that stopped just short of expressing amazement at the Board's conclusion. As the Court noted, the Board's finding was "vigorously disputed not only by the appellant, but also by the Attorney General of Canada, the Attorney General of Ontario, the Alberta Department of Energy, and an intervenor, TransGas Limited. ${ }^{162}$ Indeed, no party or intervenor had supported "the Board's assertion of federal jurisdiction over a part of an intraprovincial gas distribution system."163

\section{E. THE PESH CREEK PIPELINE}

On October 12, 1995, Novagas Clearinghouse Pipelines Ltd. ("NCPL") applied to the NEB for approval, by way of an exemption order under s. 58 of the NEB Act, of a proposed natural gas pipeline to transport gas from a proposed separation, compression and metering facility in northeastern British Columbia (referred to as the Peggo Facility) to a proposed NGTL metering facility in northwestern Alberta. The

\footnotetext{
s8 Supra note 4.

s9 Figure 3 is reproduced with the permission of the National Energy Board, supra note 4.

(b) $\quad$ bid. at 17.

6 See Summary of Submissions, ibid., c. 3.

62 Supra note 5 at 152.

63 Ibid.
} 
various facilities are illustrated in Figure 4 at p. 412 of this article, taken from the Board's "Reasons for Decision." ${ }^{164}$

By a letter dated November 21, 1995, Westcoast submitted to the Board that the proposed pipeline should not be considered under $\mathrm{s} .58$ of the $N E B$ Act, as the pipeline formed part of a larger project that included the upstream and downstream connecting facilities. ${ }^{65}$ Such upstream and downstream facilities had received provincial approvals for construction and operation. ${ }^{66}$

By a letter dated January 12, 1996, the Board notified parties of its intention to refer to the Federal Court of Appeal the question of jurisdiction over the upstream and downstream connecting facilities. However, in view of the fact that no party disputed the Board's jurisdiction over the Pesh Creek Pipeline itself, the Board proceeded to consider NCPL's application for that portion of the facilities and, in January 1996, granted the approval requested under s. $58 .{ }^{67}$ Westcoast has applied for leave to appeal the Board's decision to the Federal Court of Appeal.

Meanwhile, the Board requested comments on its January 12 decision to refer the matter of jurisdiction to the Federal Court of Appeal. Several parties have commented that the reference is now unnecessary and has, in effect, been rendered academic by the Board's approval of the Pesh Creek Pipeline. Westcoast, however, has vigorously argued that the reference should proceed and at the time of writing the matter is in the hands of the Board for decision. Should the Board decide to proceed with the reference, it is likely that, as in the earlier Westcoast case, ${ }^{68}$ Westcoast's application for leave to appeal the Board's Pesh Creek Decision would be combined with the Board's reference and that a single decision by the Court would ensue.

Again, the issue lurking in the background is the perceived risk by some parties of an incursion of federal jurisdiction into the hitherto exclusive provincial domain of jurisdiction over NGTL.

\section{F. EMERGING ISSUES}

Lest it be thought that the recent flurry of activity on the jurisdictional front is a passing phenomenon, it must be noted that there are several pipeline projects on the horizon that are likely to raise similar issues.

PanCanadian Petroleum Ltd. ("PanCanadian") has proposed the Palliser pipeline project, the purpose of which would be to bypass the NGTL system and establish a new connection to the TransCanada PipeLines Ltd. and Northern Border Pipeline Company 
systems. It appears that PanCanadian (or Westcoast, as potential owner and operator of the line) intends to apply for provincial authorization to construct the project. ${ }^{69} \mathrm{~A}$ spokesman for PanCanadian has been quoted as stating "the proposed project ... will move new supply to feed expansion projects by TransCanada PipeLines Limited and Northern Border Pipeline Company...."170 It appears that the project may have no local aspect and that it may, therefore, be essential or integral to interprovincial pipelines that are admittedly under the jurisdiction of the NEB. Again, the threat of a federal incursion into what has been largely an exclusive Alberta domain looms large.

On the east coast, the proposed Sable Offshore Energy Project may also raise jurisdictional issues similar to those considered in the Westcoast Case. The configuration of the project involves an onshore gas processing plant that will be supplied solely by a pipeline from several offshore fields and that will itself be under NEB jurisdiction. Most of the gas to be processed at the onshore plant will be transported downstream by a further transmission line under NEB jurisdiction, although there will likely also be some local, intra-provincial distribution of the processed gas. Will the plant itself fall within the NEB's jurisdiction or should it be characterized as a local, intra-provincial work?

Finally, the Alliance Pipeline project proposes a wholly new trunkline system from northeastern British Columbia, across Alberta, to the Chicago area." Such a line would obviously come within the jurisdiction of the NEB. The constitutional status of any gathering systems or laterals connected to the line, either in British Columbia or in Alberta, may not be so clear.

Based on these emerging projects, which are by no means merely speculative, it appears likely that jurisdictional issues will continue to challenge the Canadian pipeline and petroleum producing industries.

\section{SOURCE OF THE PROBLEM}

It is perhaps too easy to suggest that, to the extent there is a problem, it has its root in the activism of the NEB in taking the initiative and making an issue of jurisdiction without such question having been raised by parties to the relevant proceedings. ${ }^{72}$ The solution, according to this view, may lie in the Board simply exercising forbearance, by refraining from precipitating a jurisdictional question unless such a matter is put in issue by an interested party.

Such a view is, however, too simplistic, and of dubious legal merit. The Board must answer to its statutory mandate. It must determine whether a pipeline or associated

See J. Ludwick, "PanCanadian Proposed Pipeline to Rival NOVA in Southem Alberta" Nickles Daily Oil Bulletin (3 April 1996) 1.

Ibid.

See "IPL Enters NATS Pipeline Project" Nickles Daily Oil Bulletin (3 May 1996).

As was the case in the Altamont Decision, supra note 23, the WBI Canadian Decision, supra note 33, and the Niagara Decision, supra note 4. 
facilities come within the definition of "pipeline" as set out in s. 2 of the $N E B A^{73}$ and, in doing so, it must have regard to the source of Parliament's jurisdiction. ${ }^{74}$ The Board has to determine whether a pipeline or facilities are a work or undertaking within the meaning of paragraph 92(10)(a) of the Constitution Act, 1867. The NEB's failure to do so would be in dereliction of its statutory duty.

In any event, a refusal by the Board (whether benign or otherwise) to address the question of jurisdiction with respect to specific facilities would be of no legal consequence in settling the question. Just as there are no "constitutional squatters rights, ${ }^{175}$ constitutional jurisdiction cannot be settled by a choice on the part of an administrative agency to turn a blind eye. ${ }^{76}$ Constitutional jurisdiction can be settled by the courts, and by the courts alone. This is not an area in which curial deference is shown to the findings of specialized administrative tribunals.

Furthermore, a policy of forbearance on the part of the NEB, even if not objectionable on principle, would not address the likelihood that jurisdictional issues will be raised from time to time by third parties. ${ }^{77}$ It is noteworthy in this regard that the issue in the Westcoast Facilities Decision and the Pesh Creek Decision proceedings was not raised by the Board but by certain participants in those proceedings. ${ }^{78}$

In summary, it is the legal nature of the Canadian constitutional system that is the source of the problem. Only the courts can settle questions of constitutional jurisdiction. Neither the silence nor the consent of any government, agency or institution can alter this reality.

73 Supra note 54.

74 The interrelationship between the interpretation of "pipeline" under the NEB ACt and the process of determining whether a specific work or undertaking is an interprovincial work or undertaking was emphasized by the Federal Court of Appeal in the Westcoast Case. It will be recalled that the Court also had to determine whether Westcoast's processing plants came within the definition of "pipeline." The Court found that "a part of the answer lies in the findings on the constitutional question; once it is determined that Westcoast is a single undertaking, it seems to me to be much easier to view the processing plants as being an integral part of the pipelines to which they are connected on each side," supra note 2 at 142.

Alberta Government Telephones v. C.R.T.C. (1984), 15 D.L.R. (4th) 515, Reed J. at 538, aff'd [1989] 2 S.C.R. 225.

With respect, the strong dissents of various Board members (Fredette and Belanger in the Altamont Decision and Andrew in the Niagara Decision) overlook this fundamental fact. Those Board members each expressed concem that the Board was introducing uncertainty, which overlooks the fact that certainty would not be any more assured by a Board decision that did not address jurisdictional questions.

The submission of April 11, 1996, by counsel for Westcoast in the Pesh Creek Decision, is apropos: "The issue of constitutional jurisdiction over the pipeline facilities upstream and downstream of the Pesh Creek pipeline is anything but advisory or academic. It is not going to go away. It is open to any party at any time before either the Board or one of the provincial agencies to raise the constitutional issue afresh. The idea of the Reference is to put an end to uncertainty. The only body that can eliminate the uncertainty surrounding the issue of constitutional jurisdiction is the Court." See also supra note 64.

78 In the Westcoast Facilities Decision, the jurisdictional issue was first raised by BC Gas Utility Ltd. and in the Pesh Creek Decision by Westcoast. 
The inquiry should, therefore, shift to the question of whether there are mechanisms available under the Constitution Act, 1867 that could be employed, not to answer questions of jurisdiction through some means other than by judicial determination, but to mitigate the consequences of the uncertainty that is an inherent and permanent feature of our federal system.

\section{A SUGGESTED SOLUTION}

\section{A. INTRODUCTION}

As already indicated, at least a partial solution may be found in exploring the wellestablished mechanisms under the Constitution Act, 1867 for implementing administrative arrangements based on a delegation of authority. The concept of resorting to cooperative federal-provincial arrangements to accommodate the realities of the Canadian federation from time to time is certainly not new. Delegation techniques are widely employed ${ }^{79}$ and, indeed, one of their best known uses is with respect to interprovincial transportation. In fact, Ballem made a passing reference to the possibility of delegation as a potential political solution in the event that the NGTL system were found to come under federal jurisdiction (based on an application of the essential or integral test), but he did not elaborate. ${ }^{80}$

It is also noteworthy that there is a limited acknowledgement in the Alberta Pipeline $A c t^{81}$ of the need for some accommodation. Section 2 expressly provides that the Act does not apply to any pipeline for which there is in force a certificate or an exemption order "issued or made by the National Energy Board under the National Energy Board Act (Canada)...." While this legislative provision cannot have the effect of determining the constitutional status of specific facilities, it avoids competing jurisdictional claims in at least some cases. ${ }^{82}$

In the U.S., Congress has gone some way to addressing the overlap of jurisdiction between interstate and intrastate pipelines by adopting the Hinshaw Amendment to the Natural Gas Act, ${ }^{83}$ which defines the jurisdiction of the Federal Energy Regulatory Commission in such a way as to preserve exclusive state regulatory authority over the within-state receipt and delivery of natural gas.

The problem under the Canadian Constitution, however, is different, due to the fact that ss. 91 and 92 of the Constitution Act, 1867 establish mutually exclusive, rather than concurrent, legislative powers. Theoretically at least, the legislative authority of the provinces with respect to a local work or undertaking cannot reach an interprovincial pipeline, nor can Parliament's legislative authority with respect to interprovincial works

82 It would appear to be legally acceptable for a provincial legislature to determine that it will not seek to apply its legislation to a matter that is the subject of federal legislation. 
and undertakings reach a pipeline that is a local work or undertaking within a province. The difficulty in the Canadian context arises from determining the upstream or downstream point at which an interprovincial pipeline becomes a local work, and vice versa. A solution such as that adopted in the U.S. under the Hinshaw Amendment would not, therefore, appear to be transferable to Canada. If there is to be a solution, it must be based on principles acceptable under the Constitution Act, 1867.

\section{B. PRINCIPLES OF DELEGATION}

The principles for determining the validity of a delegation of authority between the two levels of the federal Canadian system are well settled. ${ }^{84}$

First, Parliament and the provincial legislatures cannot directly delegate their respective legislative powers to each other. ${ }^{85}$

Secondly, Parliament and the provincial legislatures can delegate the administration of their otherwise validly enacted laws to a subordinate agency that is established by validly enacted legislation of the receiving jurisdiction. ${ }^{86}$

Thirdly, Parliament and the provincial legislatures may each adopt the legislation of the other jurisdiction as their own by incorporating such legislation by reference. ${ }^{87}$ Furthermore, the ability to adopt the legislation of the other level of government extends to legislation as it may be enacted in the future. This technique is referred to in the literature as anticipatory incorporation by reference. It goes without saying that "legislation" in this context includes regulations validly made under the authority of the jurisdiction whose legislation is being adopted.

Fourthly, application of legislation enacted by Parliament or a provincial legislature may be made conditional upon some future act or event, including an act or event that is within the control of the other jurisdiction. In other words, the application of a federal law can be made conditional upon the existence of a provincial law, ${ }^{88}$ although Hogg has questioned whether some applications of this proposition may have gone too far in effectively enlarging the powers of provincial legislatures. ${ }^{89}$

Finally, these several techniques can be combined and can be used in such a way that authority is, for all practical purposes, transferred from one level of government to the other, although subject to being recalled. The scheme for the regulation of

See generally Hogg, supra note 16, c. 14.

Nova Scotia (A.G.) v. Canada (A.G.), [1951] S.C.R. 31.

P.E.I. (Potato Marketing Board) v. Willis, [1952] 2 S.C.R. 392.

Ontario (A.G.) v. Scott, [1956] S.C.R. 137.

See e.g. Gold Seal v. Dominion Express Co. (1921), 62 S.C.R. 424.

Hogg, supra note 16 at 365 , is particularly critical of the decision of the Supreme Court of Canada in Lord's Day Alliance of Canada v. British Columbia (A.G.), [1959] S.C.R. 497. 
interprovincial trucking is perhaps the best known example of the use of these techniques and serves well to illustrate the point. ${ }^{90}$

It is perhaps not so well known that the various delegation techniques can also be used if it is uncertain whether constitutional authority with respect to a particular matter lies with the federal or the provincial governments. The legislative schemes for the implementation of the Atlantic Accord ${ }^{91}$ and the Canada-Nova Scotia Accord ${ }^{92}$ for the joint federal-provincial management of oil and gas resources off the east coast are important examples.

The legislative scheme ${ }^{93}$ in both of those cases involves a federal act and a provincial act under which each level of government claims jurisdiction over certain offshore areas and then proceeds to establish a regulatory scheme for oil and gas exploration, development and production in such areas. Each of the federal and provincial acts is enacted in essentially identical terms and its administration is delegated to a single agency, the members of which are jointly appointed by the responsible federal and provincial ministers, each acting under the authority of the respective acts.

There are two significant features of this scheme that are particularly relevant. First, it is not necessary that a precise claim to constitutional authority be staked out. Thus, in the case of Nova Scotia, the basis of the province's claim is founded in $\mathbf{5 .} 8$ of the Provincial Accord Act whereby the act "applies to Nova Scotia lands within the offshore area." Paragraph 2(p) defines "Nova Scotia lands" as follows:

(p) "Nova Scotia lands" means

(i) Sable Island, and

(ii) those submarine areas that belong to Her Majesty in right of the Province or in respect of which Her Majesty in right of the Province has the right to dispose of or exploit the natural resources, and that are within the offshore area;

Thus, the Provincial Accord Act applies only to such submarine areas (and Sable Island) that in fact belong to the Crown in right of Nova Scotia or in respect of which

90 The validity of the scheme was upheld by a majority of the Supreme Court of Canada in Coughlin v. Ontario (Highway Transport Board), [1968] S.C.R. 569 [hereinafter Coughlin].

9 Memorandum of Agreement between the Government of Canada and the Government of the Province of Newfoundland and Labrador on offshore oil and gas resource management and sharing, (11 February 1985).

$92 \quad$ Canada-Nova Scotia Offshore Petroleum Resources Accord, (26 August 1986).

93 The Atlantic Accord is implemented by the federal Canada-Newfoundland Atlantic Accord Implementation Act, S.C. 1987, c. 3 and the provincial Canada-Newfoundland Atlantic Accord Implementation (Newfoundland) Act, S.N. 1986, c. 37. The Canada-Nova Scotia Accord is implemented by the federal Canada-Nova Scotia Offshore Petroleum Resources Accord Implementation Act, S.C. 1988, c. 28, and the provincial Canada-Nova Scotia Offshore Petroleum Resources Accord Implementation (Nova Scotia) Act, S.N.S. 1987, c. 3 [hereinafter Provincial Accord Act]. 
the Crown in right of Nova Scotia has the right to dispose of or exploit its natural resources. The Provincial Accord Act does not purport to apply to any areas that are not within provincial jurisdiction. Only if the province has a valid claim to a particular area does the provincial legislation apply.

Secondly, the mirror feature of the Atlantic Accord and Canada-Nova Scotia Accord schemes in effect establishes a zero sum game that minimizes the risk of constitutional challenge to the legislation of either the federal Parliament or the provincial legislature. A successful challenge to the legislation at one level would, as a necessary corollary, establish the validity of the legislation of the other level of government and hence nothing would be gained by any party subject to the scheme. The enactment of mirror legislation is not being proposed here, but the concept of the zero sum game would be an important element of the scheme that is proposed.

\section{APPLICATION TO FEDERAL PIPELINES}

What is proposed here is a combination of various elements of the foregoing principles - and the experience gained from their application in numerous federalprovincial schemes - to introduce a mechanism that could be used to reduce, if not necessarily eliminate, jurisdictional uncertainty. The essential elements may be stated very simply:

(1) The NEB would be empowered to make an order $^{94}$ designating specific facilities, or a specific point on a pipeline, for purposes of the scheme.

(2) Where such an order was made, the designated facilities, or all facilities upstream or downstream of the designated point as the case may be, to the extent such facilities came within federal jurisdiction, would thereafter be subject to the relevant regulatory scheme of the province in which such facilities were located. Appropriate measures adopting such provincial regulatory schemes for federal purposes would be included.

The various elements of the requirements for a valid delegation on which such a scheme would depend are readily identifiable.

First, application of the scheme to any specific circumstances would be conditional on the issuance of a designation order by the Board.

Secondly, the scheme would incorporate by reference the relevant provincial regulatory schemes, province-by-province, much as is done under the existing scheme for the delegation of federal jurisdiction over interprovincial transportation to provincial transport boards. ${ }^{95}$ 
Thirdly, the scheme would not require any pre-determination on the part of the Board, or by any other body, that any specific facilities in fact came within federal jurisdiction. The scheme would borrow the approach of the Provincial Accord Act, and would simply operate on the premise that if the facilities in question were within federal jurisdiction, the Board's designation order would attach thereto, with the consequence that the facilities would thereafter be regulated in accordance with provincial requirements. If any facilities that were subject to a designation order by the Board were not in fact within federal jurisdiction, provincial regulation thereof would be effective by direct application, rather than by operation of federal law.

Fourthly, the scheme would also rely on the zero sum game feature of the Atlantic Accord and Canada-Nova Scotia Accord schemes, inasmuch as a successful challenge of the jurisdictional classification of any specific facilities that were subject to a designation order would simply determine that such facilities were under provincial jurisdiction. (In such a case, the same provincial requirements would apply directly to the facilities.) If the outcome of a challenge were that specific facilities were determined to be under federal jurisdiction, the validity of the Board's designation order would thereby be confirmed and the same provincial requirements, as incorporated into federal requirements by operation of the scheme, would still apply.

\section{CONCLUSION}

This is not the place to explore how such a scheme might have been applied in past cases. Suffice it to say that the scheme could be broad enough to avoid having parts of the NGTL system regulated by the Board or, on the other hand, to allow Westcoast's processing plants and gathering system to be regulated as if under provincial jurisdiction.

Essential federal interests would be protected, as the Board would be free to retain direct authority over any facilities that it considered it should continue to regulate in order to maintain the integrity of its overall regulatory responsibilities.

The funciamental elements of the scheme are not new. What is perhaps new is the suggestion that the scheme could be applied selectively, ${ }^{96}$ rather than having the Board wholly withdraw from regulating in the sphere of federal works and undertakings, or at least in pre-defined parts thereof. This would allow the Board some flexibility to define for itself the limits of that sphere, rather than being wholly dependent upon the vagaries of judicial review of what are essentially factual determinations on a case-bycase basis. At the same time, the mechanism would hopefully allow the Board, the pipelines and the petroleum industry to avoid the costly uncertainty of the status quo, as has been so graphically reinforced by recent developments.

* The criterion for determining whether the scheme should be applied in a specific case would be the maintenance of the integrity of the overall federal regulatory scheme. 
Figure 1

Location of Applied-for Facilities in Relation to Other Selected Pipelines

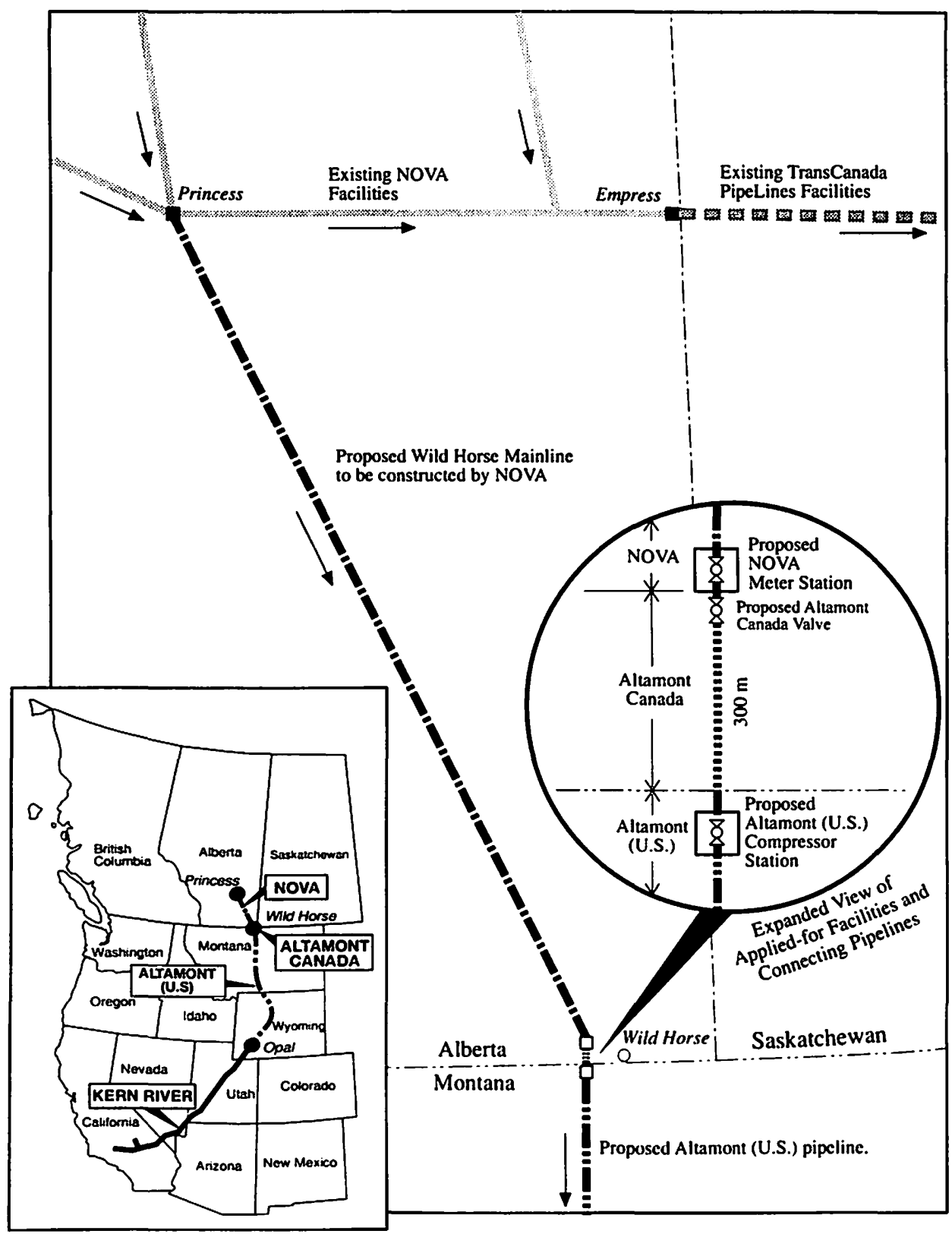

GHW-1-92 
Figure 2

Fort St. John Expansion Facility Location Map

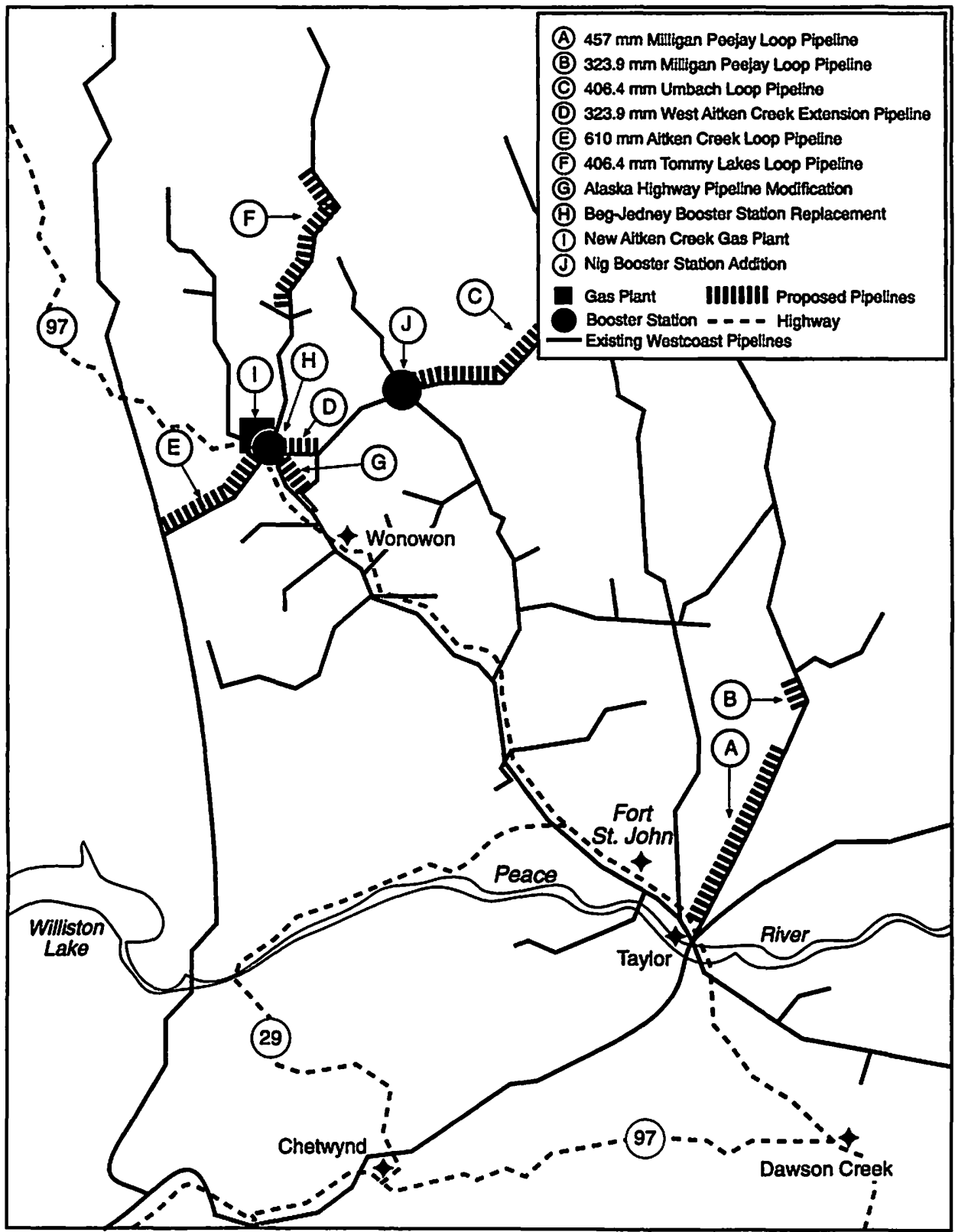

GH-5-94 
Figure 3

Consumers' Gas XHP. Pipeline System Schedule NEB-43C

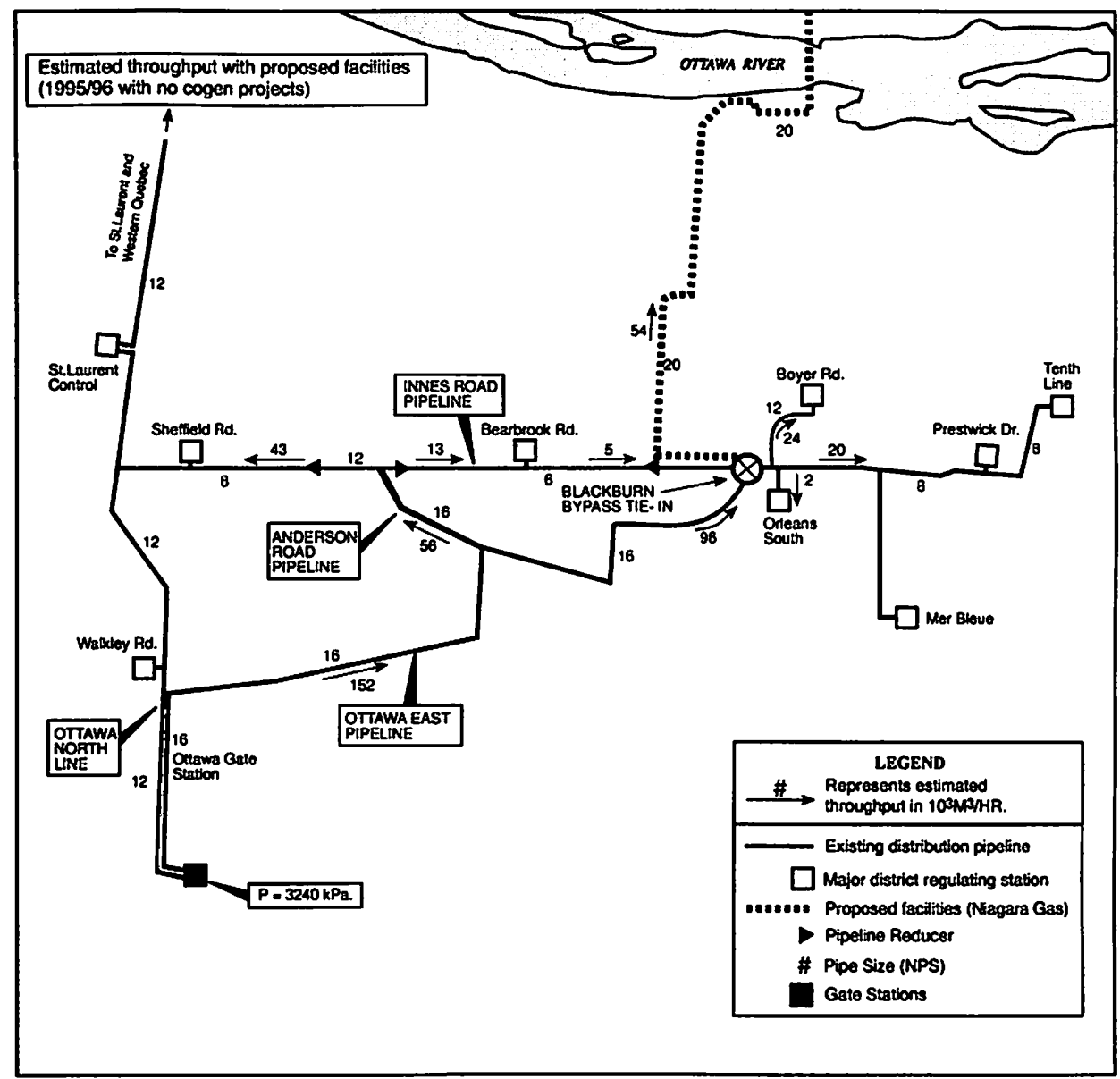

Niagara Gas - Jurisdiction 
Figure 4

Location Map: Pesh Creek Pipeline Project

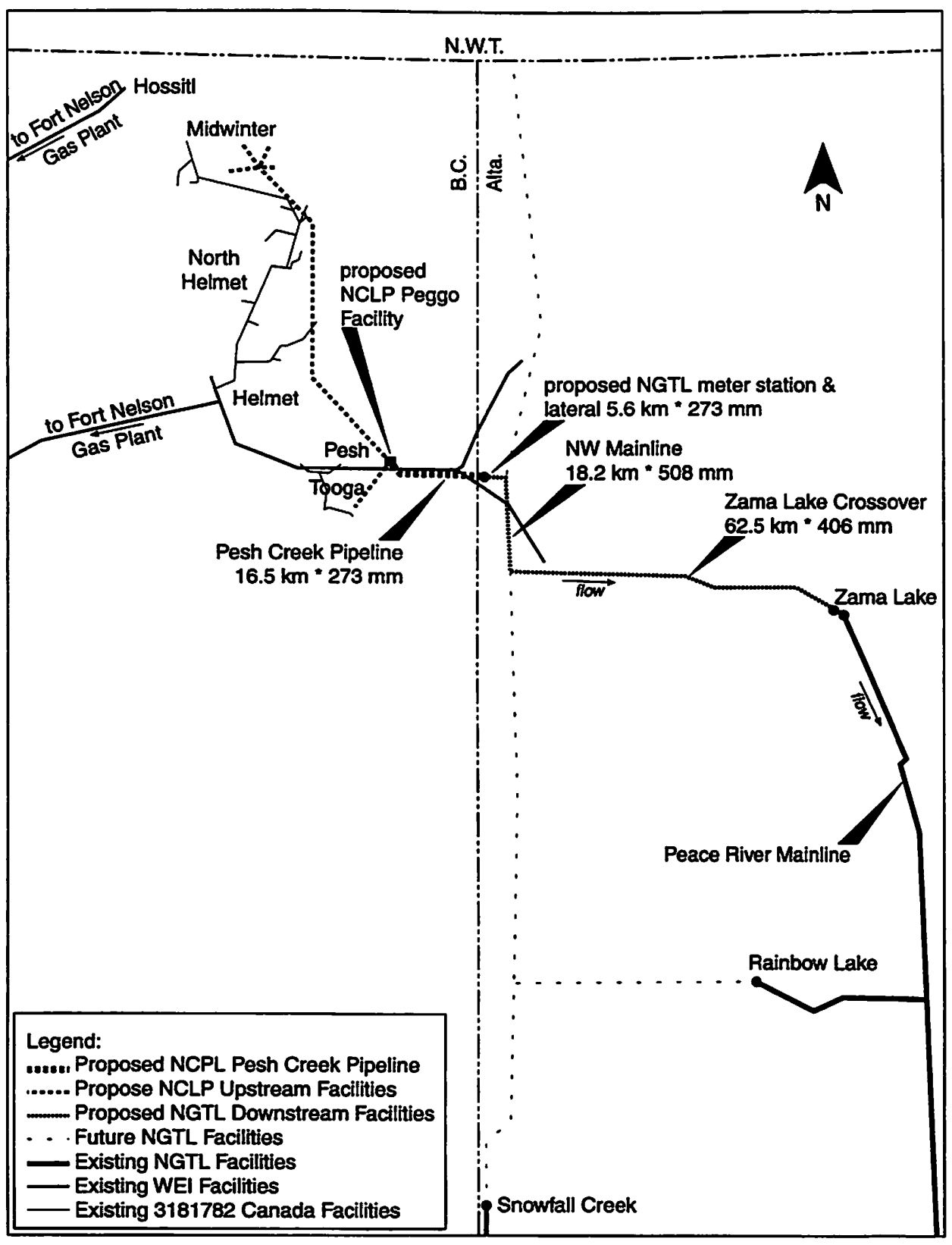

GH-1-96 